\title{
IMPROVEMENT OF WRITING SKILLS USING ACTIVITY BASED METHOD OF LEARNING AT GRADE-VI
}

\author{
Zahoor-ul-Haq \\ Bushra Ahmed Khurram**
}

\begin{abstract}
This study was undertaken to investigate the outcome of using the activity based learning method on the development of writing skills of students of grade 6. The study used pretest post-test equivalent group design. 50 students were randomly selected from a government school as sample for this study. They were divided into experimental and control groups based on the scores they achieved in pre-test. Students in the experimental group received instruction through activity based method of learning. In contrast, the traditional method of teaching writing was used for teaching the control group. A comparison of pre- and post-test scores on writing measure evidenced that the experimental group performed better that the control group on writing post-test. It was concluded that activities helped enhance the writing skills of the experimental group. This finding suggests that students of elementary level should be engaged in activity based learning to enhance their writing skills.
\end{abstract}

Keywords: Writing skill, activity based learning, low achiever, high achiever

\section{Introduction}

Activity Based Learning (henceforth, ABL) is an instructional method for classroom teaching and learning that involves learners in the process of learning in the classroom ${ }^{1}$ (Prince, 2004). Literature indicates that activity based learning methodologies encourage learners to actively contribute to the lessons. ${ }^{2}$ Put another way, during activity based learning method students actively participate in the learning experiences to construct their own knowledge based on their previous experiences. ${ }^{3}$ This is so since activity based learning is based on the theory of constructivism that states that knowledge is constructed by individuals through reflection on their experiences. ${ }^{4}$ In more detail, the constructivist view of learning points out that from birth to adulthood, when individuals encounter

\footnotetext{
* Zahoor-ul-Haq, Ph.D, Lecturer, Department of Education, Bacha Khan University Charsadda.

** Bushra Ahmed Khurram, PhD, Assistant Professor, Department of English, University of Karachi. ${ }^{1}$ Prince, M, Does active learning work? A review of the research. Journal of Engineering Education, vol. 93 (3), (2004), p. 223-231.

${ }^{2}$ Stößlein, M. Activity-Based Learning Experiences in Quantitative Research Methodology for (TimeConstrained) Young Scholars - Course Design and Effectiveness. POMS 20th Annual Conference, Orlando, Florida. U.S.A. (2009), p.1-33.

${ }^{3}$ Harfield, T., Davies, K., Hede, J., Panko, M., \& Kenley, R. Activity-based teaching for Unitec New Zealand construction students. Emirates Journal for Engineering Research. vol 12(1), (2007), p. 57-63.

${ }^{4}$ Powell, K. C. and Kalina, C. J. Cognitive and social constructivism: Developing tools for an effective classroom. Education, vol. 130 (2), (2009), p. 241-250.
} 
something new they reconcile it with their previous knowledge and experiences. This results in active construction of new knowledge..$^{5}$

Research shows that activity based method of teaching facilitates learning since it is a child-centered method which motivates learners to learn independently. ${ }^{6}$ Some researchers point out that activity based learning permits learners to work with their peers and specialists in their personal educational environment. ${ }^{7}$ Moreover, this method offers chances to students to converse and share their ideas among themselves. ${ }^{8}$ Serag $^{9}$ states that activity based learning help students to think critically and be independent learner as this method provide them the support needed in this regard.

A study conducted by Harfield et.al. ${ }^{10}$ shows that on applying activity based teaching in the class student engagement in the lessons improved markedly as compared to the previous class. Moreover, students grade in relation to the previous class significantly improved. Besides that, the study conducted by ${ }^{11}$ Churchill indicates that the method of activity based teaching facilitates development and enhancement of higher order thinking skills in students.

Bansal and Kumar ${ }^{12}$ consider activity based learning as an inventive, stimulating method for teaching as this method is helpful also in the classroom communication. Kolb ${ }^{13}$ also regards demonstrative activity based teaching more apt for facilitating learning in contrast to the traditionally used lecture based method of teaching. In sum, it appears from the literature that the activity based teaching method helps in thought-provoking, interdisciplinary, and cooperative education. ${ }^{14}$ This is why Padmavathi ${ }^{15}$ asserts that teachers of the twenty first century ought to implement inventive teaching strategies such as activity based learning methods instead of old-fashioned stressful methodologies.

\footnotetext{
${ }^{5}$ Wadsworth, B.J. Piaget's Theory of Cognitive and Affective Development: Foundations of Constructivism (5th edn). (Longman, 1971).

${ }^{6}$ Ibid.

${ }^{7}$ Domin, D. S. Students' perceptions of when conceptual development occurs during laboratory instruction. Chemistry Education Research and Practice, vol. 8 (2), (2007), p. 140-152.

${ }^{8}$ Ibid.

${ }^{9}$ Serag HN. Building the Learning Community Through Activity Based Learning Among Kg Non-Specialist EFL Teachers. Int. J. Res. Educ. Vol. 03, (2011), p. 1-28.

${ }^{10}$ Harfield, T., Davies, K., Hede, J., Panko, M., \& Kenley, R. Activity-based teaching for Unitec New Zealand construction students. Emirates Journal for Engineering Research, vol. 12 (1), (2007), p. 57-63.

${ }^{11}$ Churchill. D. Effective design principles for activity-based learning: the crucial role of 'learning objects' in Science and engineering education. Retrieved of October 10, 2011 from http://www.learnerstogether.net/PDF/Effective-Design-Principles. pdf, (2003).

${ }^{12}$ Bansal V, Kumar R. Activity Based Learning New Method of Learning: A Case Study of Teach-Next. International J. Res. Econ. Soc. Sci. vol. 2 (2), (2012), p. 414-428.

${ }^{13}$ Kolb, D. A. Experiential learning: Experience as the source of learning and development. (Englebrook, NJ: Prentice Hall, 1984).

${ }^{14}$ Tilya, F.N. Teacher Support for the Use of MBL in Activity-Based Physics Teaching in Tanzania. Thesis (University of Twente, 2003).

${ }^{15}$ Padmavathi BVV. Activity Based Learning. Res. J. English Lang. Literature. vol. 1 (3), (2013), p. 287-289.
} 


\section{Writing}

Effective writing skills are considered to be of paramount importance for success in academic and work life. ${ }^{16}$ Despite that, too many students lack the writing competence needed for carrying out the writing tasks at respective grade levels. ${ }^{17}$ Kellogg \& Whiteford argue that one of the reasons for inadequate preparation for effective writing in students is getting insufficient task practice in writing at primary, secondary and tertiary levels ${ }^{18}$. This raises the question what instructional practice develop and foster the writing skills of students. The meta-analysis of writing instructions carried out by Graham \& Perin indicate that explicit and scaffolded instruction of writing tasks and processes could help improve writing skills of students ${ }^{19}$. Moreover, using authentic writing tasks in the classroom could also foster the motivation to write in students. ${ }^{20}$

\section{Purpose of the Study}

This study investigates the outcome of using the activity based learning method on the development of writing skills of low and high achievers of 6th grade class. More specifically, the study tests the following null hypotheses:

1. Activity based learning has no effect on the improvement of writing skills.

2. Activity based learning has no effect on the enhancement of writing skills of the underperforming learners.

3. Activity based learning has no impact on the development of writing skills of the high performing learners.

In Pakistan, the improvement of writing skills through activity based learning is fairly under researched since teaching in public sector schools is done using conventional methodologies.

\section{Method and Procedure Research Design}

The current study was experimental in design and used pretest-posttest equivalent group design approach. In language learning, the experimental research is usually conducted in

16 Graham, S., \& Perin, D. A meta-analysis of writing instruction for adolescent students. Journal of Educational Psychology, vol. 99, (2007), p. 445-476.

${ }^{17}$ Persky, H. R., Daane, M. C., \& Jin, Y. The nation's report card: Writing 2002. (NCES 2003 529). U.S. Department of Education. Institute of Education Sciences. National Center for Education Statistics. (Washington, DC: Government Printing Office, 2003).

${ }^{18}$ Kellogg, R. T., \& Whiteford, A. P. Training advanced writing skills: The case for deliberate practice. Educational Psychologist, vol. 44, (2009), p. 250-266.

${ }^{19}$ Graham, S., \& Perin, D. A meta-analysis of writing instruction for adolescent students. Journal of Educational Psychology, vol. 99, (2007): 445-476.

${ }^{20}$ Bruning, R., \& Horn, C. Developing motivation to write. Educational Psychologist, vol. 35, (2000), p. $25-37$. 
a classroom in a controlled environment to understand aspects of learning of language learners. ${ }^{21}$

\section{Population}

The study population consisted of 295,575 KPK learners who were studying at Grade-VI (EMIS, 2013).

\section{Research Sample}

For the purposes of the study, 50 students were selected randomly from 6th class of Government Shaheed Waseem Iqbal High School Tarkha. Two equal groups i.e. experimental and control groups of 25 students each were formed based on the scores students achieved in the pre-test. Both groups had the students of almost the same ability. In each group, high achieving and low achieving students were also identified. The students who obtained a score above the mean in each group were named as high achiever students and those who had scored below the mean were named as low achiever students.

\section{Research instrument and procedure}

The study used pre- and post-test to measure the extent to which the participants developed their writing skills. The researcher developed the test in consultation with the language and subject experts who approved the content validity of the test. To develop the test items, in depth study of the relevant literature was carried out. The writing test of IELTS and TOEFL were also consulted. The reliability of the test was measured by using the split-half technique. The coefficient of the reliability was 0.8 which was very high. The pre-test was used to distribute sample students in experimental and control groups. The post- test was conducted at the end of the study to determine the development of writing skills of the learners. The pre- and post-tests were based on 10 items related to writing skills. These items were selected from five $6^{\text {th }}$ grade English lessons, namely, Ibne-Seena; over population in cities; The Cub; electricity, and Qissa Khwani Bazar.

Two teachers from Government Shaheed Waseem Higher Secondary Tarkha, Nowshera district, with an MA degree in English from the University of Peshawar, were engaged for teaching English to the experimental and control groups. Both teachers had relatively equal teaching experience and competencies. The teacher who taught the experimental group had already been trained by the DCTE, KPK in teaching English through activity based learning.

\section{Delimitation of the Study}

Since this study was experimental in nature, it was in the first stage delimited to $6^{\text {th }}$ grade male students of government schools in Khyber Pakhtunkhwa. It was then further delimited to only government Shaheed Waseem Iqbal Higher Secondary School Tarkha.

${ }^{21}$ Phakiti, A. Experimental research methods in language learning. (New York: Bloomsbury Publishing, 2014). 


\section{Data collection}

The research subjects of experimental group as well as control group were given the writing tests developed by the researcher at the beginning and end of the study. Since the test was standardized, the starting point was the same for both groups.

\section{Data Analysis}

The current quantitative study utilized the independent sample t-test to compare the data collected from the experimental and the control groups of the study. For each group, mean, standard deviation, and difference of means were calculated. Significance of difference on the variable of pre-test and post-test scores between the mean scores of both groups was tested at a 0.05 level. The study used SPSS program for data analysis.

\section{Results}

The study found significance difference between the mean scores of the experimental and control groups on the pre-test and post-test. The results of the study, the analysis of the results and interpretation of the results are presented below.

Table 1: Pre-test Scores of Experimental and control groups in writing skills

\begin{tabular}{|c|c|c|c|c|c|}
\hline \multirow{2}{*}{ Group } & \multirow{2}{*}{$\mathbf{N}$} & \multirow{2}{*}{ Mean } & \multirow{2}{*}{ SD } & \multicolumn{2}{|c|}{ t-value } \\
\hline & & & & Table value & Calculated value \\
\hline Experimental & 25 & 4.96 & 3.32 & \multirow{2}{*}{1.68} & \multirow{2}{*}{$0.196^{*}$} \\
\hline Control & 25 & 4.76 & 3.86 & & \\
\hline
\end{tabular}

Table 1 explains that the obtained result of $t$ was 0.196 and the table value of $t$ was 1.68. Results were tested at 0.05 (level of significance) and the degree of freedom was 48 . Hence, the table value of $\mathrm{t}(1.68)$ was greater than $\mathrm{t}(0.196)$ obtained value. Thus, null hypothesis was approved because no significant difference between the mean scores was found. In this way, the experimental and control groups were identical with respect to prior knowledge in the writing skill on pre-test.

Table 2: pre-test scores of Low achievers

\begin{tabular}{|c|c|c|c|c|c|}
\hline \multirow[b]{2}{*}{ Group } & \multirow[b]{2}{*}{$\mathbf{N}$} & \multirow[b]{2}{*}{ Mean } & \multirow[b]{2}{*}{ SD } & \multicolumn{2}{|c|}{ t-value } \\
\hline & & & & Table value & $\begin{array}{l}\text { Calculated } \\
\text { value }\end{array}$ \\
\hline $\begin{array}{l}\text { Low achievers of the } \\
\text { experimental group }\end{array}$ & 13 & 2.38 & 0.77 & \multirow{2}{*}{1.706} & \multirow[t]{2}{*}{$0.492 *$} \\
\hline $\begin{array}{l}\text { Low achievers of the control } \\
\text { group }\end{array}$ & 15 & 2.2 & 1.146 & & \\
\hline
\end{tabular}


Table 2 indicates that the calculated result of $\mathrm{t}$ was 0.492 and the table value of $\mathrm{t}$ was 1.706. Results were tested at 0.05 (level of significance) and the degree of freedom was 26. Hence, the table value of $t$ (1.706) was greater than $t(0.492)$ obtained value. Thus, null hypothesis was approved because no significant difference between the mean scores was found. In this way, the low achievers of the experimental and control groups were identical with respect to previous knowledge in the writing skill on pre-test.

Table3: Pre-test Scores of High achievers

\begin{tabular}{|c|c|c|c|c|c|}
\hline \multirow{2}{*}{ Group } & \multirow{2}{*}{$\mathbf{N}$} & \multirow{2}{*}{ Mean } & \multirow{2}{*}{ SD } & \multicolumn{2}{|c|}{ t-value } \\
\hline & & & & $\begin{array}{l}\text { Table } \\
\text { value }\end{array}$ & $\begin{array}{l}\text { Calculated } \\
\text { value }\end{array}$ \\
\hline $\begin{array}{l}\text { High achievers of the experimental } \\
\text { group }\end{array}$ & 12 & 7.75 & 2.67 & \multirow{2}{*}{1.725} & \multirow{2}{*}{$-0.675^{*}$} \\
\hline High achievers of the control group & 10 & 8.6 & 3.24 & & \\
\hline
\end{tabular}

$\begin{array}{lll}* \text { Not Significant } & \text { d.f }=20 & \text { Significance level }=0.05\end{array}$

Table 3 reflects that the obtained result of $t$ was -0.675 and the table value of $t$ was 1.725 . Results were tested at 0.05 (level of significance) and the degree of freedom was 20 . Hence, the table value of $\mathrm{t}(1.725)$ was greater than $\mathrm{t}(-0.675)$ obtained value. This is why the null hypothesis was approved because no significant difference between the mean score was found. In this way, the high achievers of the experimental and control groups were the same with respect to former knowledge in the writing skill on pre-test.

Table 4: Post-test Score of experimental and control group

\begin{tabular}{|l|l|l|l|l|l|}
\hline \multirow{2}{*}{ Group } & \multirow{2}{*}{ N } & \multirow{2}{*}{ Mean } & \multirow{2}{*}{ SD } & \multicolumn{2}{|c|}{ t-value } \\
\cline { 3 - 4 } & & & & Table value & Calculated value \\
\hline Experimental & 25 & 21.24 & 4.60 & & $7.59 *$ \\
\hline Control & 25 & 9.64 & 6.09 & & \\
\hline * Significant & & & & \multicolumn{3}{|c}{ Significance level $=0.05$}
\end{tabular}

Table 4 reflects that the obtained result of $t$ was 7.59 and the table value of $t$ was 1.68. Results were tested at 0.05 (level of significance) and the degree of freedom was 48 . Hence, the table value of $t$ (1.68) was less than $t$ (7.59) obtained value. This is why the null hypothesis was discarded because significant difference between the mean sores of experimental and control group was found. In this way, the group who were taught 
through activity based learning showed superiority over the control group with respect to achievement in the writing skill on post-test.

Table 5: Post-test score of Low achievers

\begin{tabular}{|c|c|c|c|c|c|}
\hline \multirow[b]{2}{*}{ Group } & \multirow[b]{2}{*}{$\mathbf{N}$} & \multirow[b]{2}{*}{ Mean } & \multirow[b]{2}{*}{ SD } & \multicolumn{2}{|c|}{ t-value } \\
\hline & & & & $\begin{array}{l}\text { Table } \\
\text { value }\end{array}$ & $\begin{array}{l}\text { Calculated } \\
\text { value }\end{array}$ \\
\hline $\begin{array}{lcll}\text { Low achievers } & \text { of } & \text { the } \\
\text { experimental group } & & \end{array}$ & 13 & 18.76 & 2.74 & \multirow{2}{*}{1.706} & \multirow{2}{*}{$15.39^{*}$} \\
\hline $\begin{array}{l}\text { Low achievers of the control } \\
\text { group }\end{array}$ & 15 & 6.06 & 1.53 & & \\
\hline
\end{tabular}

Table 5 indicates that the obtained result of $\mathrm{t}$ was 15.39 and the table value of $\mathrm{t}$ was 1.706. Results were tested at 0.05 (level of significance) and degree of freedom was 26 . Hence, the table value of $t(1.706)$ was less than $t$ (15.39) obtained value. This is why the null hypothesis was discarded because significant difference between the mean scores of high achievers of the experimental and control groups was found. In this way, the low achievers who were taught through activity based learning outscored the low achievers of the control group with respect to achievement in the writing skill on post-test.

\begin{tabular}{|c|c|c|c|c|c|}
\hline \multirow{2}{*}{$\begin{array}{l}\text { Table 6: Post-test score of High } \\
\text { achievers Group }\end{array}$} & \multirow{2}{*}{$\mathbf{N}$} & \multirow{2}{*}{ Mean } & \multirow{2}{*}{ SD } & \multicolumn{2}{|c|}{ t-value } \\
\hline & & & & $\begin{array}{l}\text { Table } \\
\text { value }\end{array}$ & $\begin{array}{l}\text { Calculated } \\
\text { value }\end{array}$ \\
\hline $\begin{array}{l}\text { High achievers of the experimental } \\
\text { group }\end{array}$ & 12 & 23.91 & 4.79 & \multirow{2}{*}{1.725} & \multirow{2}{*}{$3.702 *$} \\
\hline $\begin{array}{l}\text { High achievers of the control } \\
\text { group }\end{array}$ & 10 & 15 & 6.49 & & \\
\hline
\end{tabular}

Table 6 depicts that the calculated value of $\mathrm{t}$ was 3.702 and the table value of $\mathrm{t}$ was 1.725 . Results were tested at 0.05 (level of significance) and the degree of freedom was 20. Hence, the table value of $\mathrm{t}(1.725)$ was less than $\mathrm{t}$ (3.702) obtained value. This is why, the null hypothesis was discarded because significant difference between mean scores of high achievers of the experimental and control groups was found. In this way, the high achievers who were taught through activity based learning outscored the high achievers of the control group with respect to achievement in writing skill on post-test. 


\section{Discussion}

The analysis of the data showed that there were no significant differences in the pretest scores of writing skills between the experimental and control groups. The data also showed that the difference between pre-test scores of underperforming students in the experimental and control groups in the writing skills was insignificant at the (0.05) level.

| This indicates that the -underachieving students in both groups had similar competence in writing at the start of the experiment. The analysis of the pre-test score further revealed that high achievers in the experimental group and the control group were almost similar at the onset of the study. These findings suggest that there was not much difference among the experimental and control group. Hence, both the groups could be treated as equal.

Besides that, the findings of the study showed that the students who were taught writing through activity-based learning method scored significantly better on the post-test than those who learned through conventional teaching methods. This finding supports and reinforces the finding of existing literature that indicate that students can acquire the competence in language skills including writing skills if they are exposed to activities related to the specific skills ${ }^{22}$ (Watkins, 2007).

The data also revealed that the low achievers of the experimental group showed better performance over the high achieving student in the control group. As a result, the null hypothesis has been abandoned. The better performance of the students of the experimental group could be due to the reason that the activity based learning provided students opportunities to actively participate in learning experiences rather than to remain passive recipients of knowledge in the classroom. This finding is in line with ${ }^{23}$ Padmavathi contention that teachers of the twenty first century ought to implement inventive teaching strategies such as activity based learning instead of old-fashioned stressful methodologies to bring positive results in the classroom.

Similarly, the difference between the mean scores of high achieving students in the experimental groups and the control groups with respect to writing performance was also significant at the (0.05) level. For this reason, the null hypothesis has been ruled out in favor of the experimental group. This finding is consistent with existing research that indicates that activities related to real-world experiences help students convert their information into knowledge and can be used in many different circumstances.

\section{Conclusions}

It was concluded from the analysis of data that the experimental group who had learned through activity based learning performed better since they remained active and involved during learning. Moreover, activity based method offered students many opportunities to develop their writing skills. Not surprisingly, therefore, the learning outcomes of the

\footnotetext{
${ }^{22}$ Watkins, P. Learning to Teach English: A Practical Introduction for New Teachers. (New Delhi: Viva Books Private Limited, 2007).

${ }^{23}$ Padmavathi BVV. Activity Based Learning. Res. J. English Lang. Literature. vol.1 (3), (2013), p. 287-289.
} 
students who were taught using activity based method dominated the outcome of those students who learned writing through traditional methods of teaching writing.

The lowest performers in the experimental group showed a significant jump from the group with the lowest scores in the control group after the writing test. The lowest performers in the experimental group participated more in learning activities. The results also showed that high performing students who were trained by activity based method showed better performance in the writing skills than those who took traditional classes on writing because the activities that were designed keeping principles of activity based learning method in view were more engaging.

\section{Recommendations}

Based on the results of the present study, following pedagogical recommendations are made:

The study showed that activity based learning method fostered students writing skills. It is therefore recommended that this method may be used to enhance the writing skills of students.

Moreover, the study showed that using an activity based learning approach for teaching requires competence and preparation on the part of the teacher. It therefore seems appropriate to suggest that teachers who choose to facilitate lessons using activity based method should be given training on how to implement this method before they step into the classroom.

The study also highlighted that use of activities in the classroom can take lots of time if the lessons are not properly planned. It is therefore recommended that teachers consider time an important factor when planning and executing an activity. They should design activities that are neither too short nor too long. In addition, teachers should conduct engaging and demanding activities that strikes a fine balance between what the learner finds familiar and what he/she finds challenging.

The study also recommends that those who design English programs in schools should support and promote activity based teaching method in their respective education institutes. They should also design, adapt or adopt a wide variety of activities to help facilitate learning in the classroom.

\section{Bibliography}

Bansal, V. \& Kumar, R. "Activity Based Learning New Method of Learning: A Case Study of Teach-Next”. International J. Res. Econ. Soc. Sci, vol. 2 (2). (2012).

Baker, J., \& Westrup, H. The English language teacher's handbook. (London: Bloomsbury Group: Continuum, 2000). 
Berman, R. \& Cheng, L. English academic language skills: perceived difficulties by undergraduate and graduate students, and their academic achievement. Canadian Journal of Applied Linguistics, vol. 4 (1-2), (2010).

Bruning, R., \& Horn, C. Developing motivation to write. Educational Psychologist, vol. $35,(2000)$.

Fitzgerald, J. English-as-a-second-language reading instruction in the United States: A research review. Journal of Reading Behavior, vol. 27, (1995).

Graham, S., \& Perin, D. A meta-analysis of writing instruction for adolescent students. Journal of Educational Psychology, vol. 99, (2007).

Hein, G. Constructivist learning theory. Retrieved from on 19 November 2011. http://www.exploratorium.edu/IFI/resources /constructivistlearning.html, (1991).

Jones, C. D., Reutzel, D. R., \& Fargo, J. D. Comparing two methods of writing instruction: Effects on kindergarten students' reading skills. The Journal of Educational Research, vol. 103 (5), (2010).

Lee, $\mathrm{H}$. The reading response e-journal: An alternative way to engage low-achieving EFL students. Language Teaching Research, vol. 17 (1), (2012).

Mercer, N. English as a classroom language. In N. Mercer \& J. Swann (Eds.), Learning English development and diversity (pp. 119-147). (New York: Routledge, 1998).

Murray, P., Donohoe, S., \& Goodhew, S. Flexible learning in construction education: A building pathology case study. Structural Survey, vol. 22 (5), (2004).

Nesamalar, C., Saratha, S. \& Teh, S. ELT Methodology: Principles and Practice. (Selangor: Penerbit Fajar Bakti, 2001).

Numan, D. Language teaching methodology: A textbook for teachers. (New York: Prentice Hall, 1991).

Panko, M., Kenley, R., Davies, K., Piggot-Irvine, E., Allen, B., Hede, J. \& Harfield, T. Learning styles of those in the building and construction sector. Report for Building Research New Zealand, Inc. Unitec New Zealand, Auckland, (2005).

Patil, Z. N. Rethinking the objectives of teaching English in Asia. Asian EFL Journal, vol. 10 ( 4), (2008).

Persky, H. R., Daane, M. C., \& Jin, Y. The nation's report card: Writing 2002. (NCES 2003-529). U.S. Department of Education. Institute of Education Sciences. National Center for Education Statistics. (Washington, DC: Government Printing Office, 2003).

Phakiti, A. Experimental research methods in language learning. (New York: Bloomsbury publishing, 2014). 
Pour-Mohammadi, M., Zainol Abidin, M., \& Cheong Lai, F. The effect of process writing practice on the writing quality of form one students: A Case Study. Asian Social Science, vol. 8 (3), (2012).

Shah I, Rahat T. Effect of Activity Based Teaching Method in Science, Int. J. Human. Manage. Sci. vol. 2 (1), (2014).

Shaughnessy, M.P. Diving in: An introduction to basic writing. In G. Tate \& E.P.J. Corbett. The Writing Teacher's Sourcebook 297-302. (New York: Oxford, 1988).

Stößlein M. Activity-Based Learning Experiences in Quantitative Research Methodology for (Time-Constrained) Young Scholars - Course Design and Effectiveness. POMS 20th Annual Conference, Orlando, Florida. U.S.A. (2009).

U.S. Department of Education, National Center for Education Statistics. The Condition of Education 2011 (NCES 2011-045), Indicator 6, (2012).

Suydam, M. N., \& Higgins, J. L. Activity-based learning in elementary school mathematics: Recommendations from research. (Columbus, Ohio: ERIC/SMEE, 1997).

Watkins, P. Learning to Teach English: A Practical Introduction for New Teachers. (New Delhi: Viva Books Private Limited, 2007).

Wyse, D., \& Jones, R. Teaching English language and literacy. (London: Taylor \& Francis Group, 2001). 